\title{
Anthropometric Dimensions of Marma (Vital Area) Present in Human Body with Special Reference its Clinico-Surgical Importance in Present Scenario
}

\author{
Lahange MS ${ }^{1 *}$ Archana Bhangare ${ }^{1}$ and Vikash Bhatnagar ${ }^{2}$ \\ ${ }^{1}$ Department of Sharir Rachana NIA, India \\ 2Department of Kayachikitsa, Mahtma Jyotiba Fule Ayurved College, India
}

*Corresponding author: Lahange Sandeep Madhukar, Department of Sharir

\section{Research Article \\ Volume 2 Issue 7}

Received Date: September 07, 2018

Published Date: September 28, 2018

DOI: $10.23880 /$ jonam- 16000153

Rachana NIA, Jaipur 302002, India, Email: sandiplahange@gmail.com

\section{Abstract}

References of Marma are found since Vedic literature. In Ayurveda, concept of Marma was first documented by Acharya Charaka but the detailed description of Marma Sharir along with its viddha lakshana is available in Sushrut Samhita. Acharya Sushruta stated every aspect of Marma like definition, location and its clinical aspect. The total numbers of Marma as described in Samhitas are 107 in number. Twelve Pranas and the vital energy of the body are the contents of the Marma sthana. As Marma are vital points of the body they should be protected from any injury. Acharya Sushruta believes that understanding of Marma Sharir covers the half knowledge of surgery. Any injury to these points may results into sever pain or death and even though the physician expert in Marma therapy treated the patient it will cause some deformity. Marma are also sites of Tridosha and Triguna. Hence, these are specific areas of the body which is directly related to Pranik channels to internal organs. Marmas are said to be the sites where there is the conglomeration of mamsa, sira, snayu, asthi and sandhi and also at these places prana resides specially by nature. The severity of the injury depends upon the site, depth of wound; intensity and time duration go off after injury. To prevent these vital points from any types of injuries everyone must knows its location, anthropometric dimension, vitality and ill effects after injuries.

Keywords: Anthropometric Dimensions; Human Body; References of Marma; Ayurveda

\section{Introduction}

Ayurveda is the ancient medical science which deals with physical as well as psychological health of the human being. In Ayurvedic classics vital force termed as Prana which emphasized in equivalence to the subtle life force energy for the existence of mankind. To understanding of the term Prana we must need to understanding different structures of the human body. The term Atmas swaroopa is coined for Prana due to its existence all over the body, but still its roots being embedded in precise location of human structure. The point of union of five basic human structures that is Mamsa, Sira, Snayu, Asthi and Sandhi is one such unique location explained in classics where this vital life force energy is residing1. In other words they can be defined as the complex anatomical sites, where a definite physiology rests and produce specific traumatic effects. These specific locations are explained as concept 


\section{Journal of Natural \& Ayurvedic Medicine}

of Marma Shareera in ayrvedic samhitas. References of Marma are found since Vedic literature. Valmiki Ramayana and Mahabharata also described the Marma. In Ayurveda, Marma was first documented by Acharya Charak. The detailed description of Marma Sharir is available in Samhitas. Acharya Sushruta stated every aspect of Marma like definition, signs and symptoms of Marma injury. The total numbers of Marma as described in Samhitas are 107 in number. Twelve Pranas, the vital energy of the body, are the contents of the Marma sthana. As Marma are vital points of the body they should be protected from any injury [1]. Acharya Sushruta believes that Marma Sharir covers the half knowledge of surgery. Any injury to these points may results into death and physician expert in Marma therapy, patient will cause some deformity. Marma are also sites of Tridosha and Triguna. Hence, these are specific areas of the body which is directly related to Pranik channels to internal organs. Acharya Sushruta explains the Marmaviddha Lakshanas in detail, for example- injury to Lohitaksha Marma, there will be death due to excessive bleeding. According to Maharshi Sushruta, there are four main types of Marma and they are as follows.

- According to Rachana (structures)

- According to Aghataj Parinaam (signs after trauma)

- According to Parimaan(anthropometric dimension)

- According to Shadanga Sharir(Region wise)

\section{According to Rachana (structures)}

Marma's are of five types- mamsa, sira, snayu, asthi and sandhi Marma. Sushutacharya further stated that these five elements are the only constitution of Marma and without these five elements Marma's are not exist. But apart from this Acharya Vagbhata added the sixth element in this above mention constitution; he stated that, we must add "Dhamani" in the constitution and stated that dominance of any one of these six elements decides the type of Marma (Tables 1-4) (Figure 1) [3-5].

\begin{tabular}{|c|c|c|c|}
\hline Sr. No. & Name of Marma & Acharya Sushruta & Acharya Vaghata \\
\hline 1 & Mamsa Marma & 11 & 10 \\
\hline 2 & Sira Marma & 41 & 37 \\
\hline 3 & Snayu Marma & 27 & 23 \\
\hline 4 & Asthi Marma & 8 & 20 \\
\hline 5 & Sandhi Marma & 20 & 9 \\
\hline 6 & Dhamani Marma & Not Explained & 9 \\
\hline
\end{tabular}

Table 1: Showing classification of Marma according to Rachana presents at the location.

\begin{tabular}{|c|c|c|}
\hline Sr. No. & Name of the Marma & Sankhya \\
\hline 1 & Sadhya Pranhar Marma & 19 \\
\hline 2 & Kalantar Pranhar Marma & 3 \\
\hline 3 & Vishalyagnya Marma & 44 \\
\hline 4 & Vaikalyakar Marma & 8 \\
\hline 5 & Rujakar Marma & \\
\hline
\end{tabular}

Table 2: Showing classification of Marma according to Parinaam (effect of injury) presents at the location.

\begin{tabular}{|c|c|c|}
\hline Sr. No. & Part of Shadanga Sharir & Number of Marma \\
\hline 1 & Dekshin Urdhva Shakha (Right Upper Extremity) & 11 \\
\hline 2 & Vaam Urdhva Shakha (Left Upper Extremity) & 11 \\
\hline 3 & Dekshin Adhah Shakh a(Right Lower Extremity) & 11 \\
\hline 4 & Vaam Adhah Shakha (Left Lower Extremity) & 11 \\
\hline \multirow{3}{*}{5} & Madhya Sharir (trunk) & 9 \\
\cline { 2 - 3 } & Urah(thorax) & 3 \\
\cline { 2 - 3 } & Udar(abdomen) & 14 \\
\hline 6 & Prushtha(back) & 37 \\
\hline
\end{tabular}

Table 3: Shows classification of Marma according to Shadanga Sharir. 


\section{Journal of Natural \& Ayurvedic Medicine}

\begin{tabular}{|c|c|c|c|c|c|}
\hline Sr. no. & Name of the Marma & Total number & Sushruta (19) & Ashtang Sangraha (20) & Ashtang Hrudaya (21) \\
\hline 1 & Adhipati & 1 & $1 / 2$ angula & $1 / 2$ angula & $1 / 2$ angula \\
\hline 2 & Aani & 4 & $1 / 2$ angula & $1 / 2$ angula & $1 / 2$ angula \\
\hline 3 & Ansa & 2 & $1 / 2$ angula & $1 / 2$ angula & $1 / 2$ angula \\
\hline 4 & Ansaphalak & 2 & $1 / 2$ angula & $1 / 2$ angula & $1 / 2$ angula \\
\hline 5 & Apang & 2 & $1 / 2$ angula & $1 / 2$ angula & $1 / 2$ angula \\
\hline 6 & Apstambha & 2 & $1 / 2$ angula & $1 / 2$ angula & $1 / 2$ angula \\
\hline 7 & Aplap & 2 & $1 / 2$ angula & $1 / 2$ angula & $1 / 2$ angula \\
\hline 8 & Aavart & 2 & $1 / 2$ angula & $1 / 2$ angula & $1 / 2$ angula \\
\hline 9 & Bruhati & 2 & $1 / 2$ angula & $1 / 2$ angula & $1 / 2$ angula \\
\hline 10 & Indrabasti & 4 & $1 / 2$ angula & $1 / 2$ angula & $1 / 2$ angula \\
\hline 11 & Guda & 1 & Swa-Panital & Swa-panital & Swa-panital \\
\hline 12 & Gulpha & 2 & 2 angula & 2 angula & 2 angula \\
\hline 13 & Hruday & 1 & Swa-panital & Swa-panital & Swa-panital \\
\hline 14 & Janu & 2 & 3 angula & 04 angula & 03 angula \\
\hline 15 & Kashakdhara & 2 & 01 angula & 01 angula & 01 angula \\
\hline 16 & Katiktarun & 2 & $1 / 2$ angula & $1 / 2$ angula & $1 / 2$ angula \\
\hline 17 & Krukatika & 2 & $1 / 2$ angula & $1 / 2$ angula & $1 / 2$ angula \\
\hline 18 & Kshipra & 4 & $1 / 2$ angula & $1 / 2$ angula & $1 / 2$ angula \\
\hline 19 & Kukundara & 2 & $1 / 2$ angula & $1 / 2$ angula & $1 / 2$ angula \\
\hline 20 & Kurcha & 4 & Swa-panital & Swa-panital & Swa-panital \\
\hline 21 & Kurchshira & 4 & 01 angula & 01 angula & 01 angula \\
\hline 22 & Kurpara & 2 & 3 angula & 04 angula & 03 angula \\
\hline 23 & Lohitaksha & 4 & $1 / 2$ angula & $1 / 2$ angula & $1 / 2$ angula \\
\hline 24 & Manibandha & 2 & 02 angula & 02 angula & 02 angula \\
\hline 25 & Mannya & 2 & Swa-panital & Swa-panital & Swa-panital \\
\hline 26 & Matruka & 8 & Swa-panital & Swa-panital & Swa-panital \\
\hline 27 & Nabhi & 1 & Swa-panital & Swa-panital & Swa-panital \\
\hline 28 & Nila & 2 & Swa-panital & Swa-panital & Swa-panital \\
\hline 29 & Nitamba & 2 & $1 / 2$ angula & $1 / 2$ angula & $1 / 2$ angula \\
\hline 30 & Parshwa-sandhi & 2 & $1 / 2$ angula & $1 / 2$ angula & $1 / 2$ angula \\
\hline 31 & Phana & 2 & $1 / 2$ angula & $1 / 2$ angula & $1 / 2$ angula \\
\hline 32 & Shankha & 2 & $1 / 2$ angula & $1 / 2$ angula & $1 / 2$ angula \\
\hline 33 & Shringhatak & 4 & Swa-panital & Swa-panital & Swa-panital \\
\hline 34 & Simant & 5 & Swa-panital & Swa-panital & Swa-panital \\
\hline 35 & Stanmula & 2 & 02 angula & 02 angula & 02 angula \\
\hline 36 & Stanrohit & 2 & $1 / 2$ angula & $1 / 2$ angula & $1 / 2$ angula \\
\hline 37 & Sthapani & 1 & $1 / 2$ angula & $1 / 2$ angula & $1 / 2$ angula \\
\hline 38 & Talahruday & 4 & $1 / 2$ angula & $1 / 2$ angula & $1 / 2$ angula \\
\hline 39 & Urvi & 4 & 01 angula & 01 angula & 01angula \\
\hline 40 & Utkshepa & 2 & $1 / 2$ angula & $1 / 2$ angula & $1 / 2$ angula \\
\hline 41 & Vasti & 1 & Swa-panital & Swa-panital & Swa-panital \\
\hline 42 & Vidhur & 2 & $1 / 2$ angula & $1 / 2$ angula & $1 / 2$ angula \\
\hline 43 & Vitap & 2 & 01 angula & 01 angula & 01angula \\
\hline
\end{tabular}

Table 4: Shows classification of Marma according to Parimaan(Anthropometric Dimension). 


\section{Journal of Natural \& Ayurvedic Medicine}

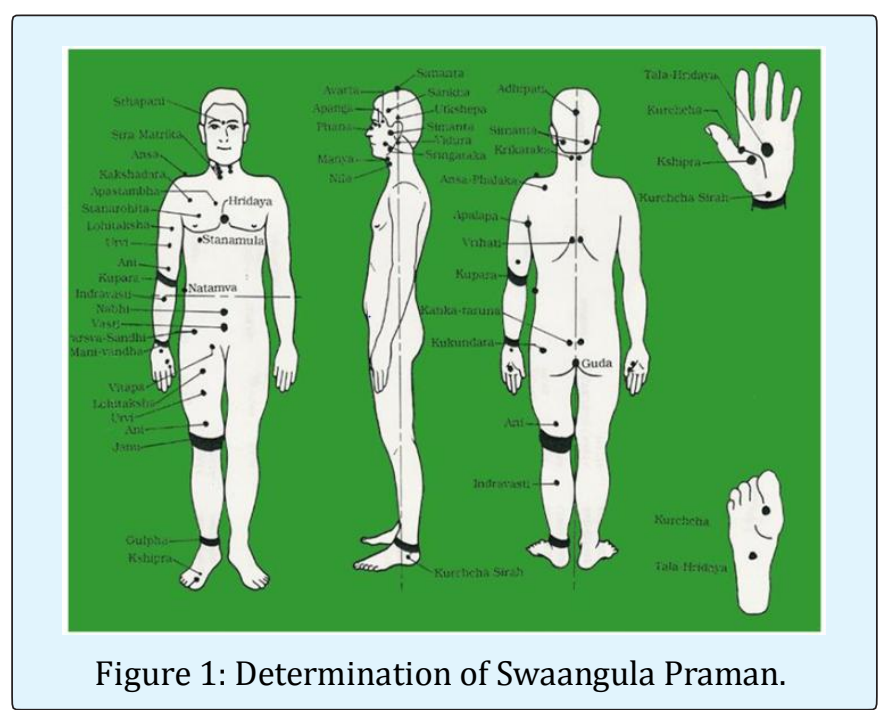

Swaangula Praman

Measurement is determination of the magnitude of a quantity by comparing with a standard for the same. A definite sate of standard unit having consistent interrelation, used to determine magnitude of a entity can be called as measurement system [6-9]. Measures were among the earliest tools invented by human. Primitive societies needed rudimentary measures for many tasks: constructing dwelling of an appropriate size and shape of, fashioning clothing and bartering food or raw materials. Human understand ably turned first to parts of his body and his natural surroundings for measuring instruments. Early Babylonian and Egyptian records, and the Bible, indicate that length was first measured with the forearm, hand, or finger. In modern era metric system first came about in the 1790 when French academy of science was asked to construct a new system of unit for use throughout the world the current international standard metric system (SI) unites accepted by the $11^{\text {th }}$ conference of weights and measures in 1960 [10-13].

Finger is an ancient and absolute non-SI unit of measurement of length. It was originally based on the breadth of a human finger. Among the prevalence system of unit it was a fundamental unit of length. Swaangula as a unit measurement seems to be more natural and scientific method. Ayurveda has given importance to individualistic approach rather than a generalized one [14-16].

\section{General Symptoms of Marma Abhighatha}

While explaining the shastra karma vyapat, Acharya Sushruta mentions the common symptoms occurred to any marma sthana due to injuries. These symptoms are also produced as a result of complication of an improperly performed surgical operation, where in injury to a marma sthana may happen.

- Bhrama- feeling of giddiness as though circling in a wheel

- Pralapa- irrelevant talk

- Patanam- inability to be in erect posture

- Pramoha- a state of semi consciousness

- Vicheshtanam- any abnormal movement of body, whether increased movement or decreased movement can be considered

- Samlayanam- a state of complete unconsciousness

- Ushnatha- increase in body temperature

- Srasthangatha- weakness of body parts

- Moorcha- decreased level of consciousness

- Urdhvavata- belching or increased expirations

- Severe pain or different types of pain due to vata.

- Flowing out of blood resembling meat wash.

- Absence of contact or abnormal contact between indriya and indriyartha resulting in loss of indriya indriyaartha sannikarsha.

The above symptoms are the common symptoms found when all the 05 marma components viz. Mamsa, sira, snayu, asthi and sandhi are getting injured together.

\section{Marma beyond Surgery}

Susrutacharya himself explains that the otherwise curable diseases being located in marma generally becomes very difficult to cure though treated with all effort.35. An injury need not always be violent, many a time mild constant irritation to marma can lead to diseases. While explaining the Roga Margas, the second Rogamarga is related with Marma, Asthi and Sandhi. Further it is explained that diseases affecting the Madyama Marga are difficult to cure. So not only for surgeons, all physicians irrespective of their discipline should have a clear idea about these vital points [17].

\section{Antah (Peripheral Region) Viddha and Madhya Viddha Lakshana}

The structure of the Marma generally includes 2 parts, Madhya and Antah (peripheral region) parts.

Madhya Viddha (central region) i.e. Injury to the Madhya (central part) of the Marma occurs, and then cardinal symptoms related to particular Marma appears like as; Shankha Marma Madhya Viddha leads to death. 


\section{Journal of Natural \& Ayurvedic Medicine}

While in Antah (peripheral region) Viddha i.e. Injury to the Antah (peripheral region) pradesha of the Marma occurred then instead of showing cardinal signs; it converted in to successive Marma lakshana.

\section{Effect of Intensity of Injury to the Marma points}

Sushrutacharya stated that if intensity of marma is not severe then result of injury may be different from the site mentioned in the particular marma injury [18]. If sadyapranhara marma gets hurts even at the last it leads to death. Peripheral injured kalantara pranhara marma turns into vaikalyakara marma (forms deformity) and Peripheral injured vishalyaghnya marma results in to sign of vaikalyakara marma. Similarly vaikalyakara marma, if injured in the Peripheral it shows symptoms like kalantara pranhara marma and mildly injured rujakara marma does not exhibit much pain. It is also fact that signs reflects not only as par the intensity of the marma but also depends upon the site of Marma.

\section{Discussion}

The anthropometric dimensions of Marma points are an extremely extensive research for every ayurvedic clinician. It is useful in various types of trauma due to different factors of body as well incidents occurring during various surgeries, removal of varied types of foreign bodies from different areas of body, warfare wounds, attacks of wild animals during those days and also the various troubles of Panchkarma therapy. The severity of Marma has been evaluated as above where post trauma commonly gives healing results. But sushruta has already emphases regarding the alteration of the post traumatic result depending upon the severity irrespective of the site [19].

The clinical aspect of Marma is elaborated by Sushruta was to avoid damage or injury to the important structure during surgery. Acharya Charaka explains the concept of TriMarma while considering the origin and practical utility of Marma. It provides great importance to the three Marma namely Shir, Hridaya and Basti out of 107 Marma and for that reason contained in the ten Pranayatana. The anthropometric knowledge of Marma is of more useful during Surgery, because of the fact that injury to the Marma point, may lead to loss of life immediately or later by problems or result in deformity of a specific area of the body. Surgeon must know the dimension of every Marma and the harms of the Marma point injury so that he can make incision carefully while during any surgical condition. This raises the query that under present advancement of the surgery any kind of Marma and subsequent predominant anatomical structure is manageable? Sushruta has already answered the query by the observation mentioned in the classical books. It also shows the awareness of the future development of the surgery which may possibly indicates the prognostic status of different Marma mentioned in ancient period [17].

Conclusively it may be said that intensity of trauma may alter the prognostic state of Marma. However a skill surgeon may save the patient from disaster. The importance of surgical tissue has been laid down with respect to mode of injury, its dimensions and the kind of weapon used, this also shows that classical view is not conservative on prognostic status of any Marma and prospective development of weaponry was anticipated. Sushruta was also considered in the Traumatology the importance of management given to the patient, which is confirmed by war experiences. Despite the discoveries since the period of Sushruta organized care of the acute injured is comparatively recent innovation [15].

As result of improvement which enhanced the expertise of Vaidya (doctor) the morality rate dropped markedly to $4.5 \%$ in World War II which has already been mentioned in classical note of Sushruta that skilled Vaidya can save the trauma person inflicted at Marma sthana but not before the cost of residual loss. Mortality and morbidity were both shown to improve if patients with the serious wounds were evacuated within ten days after wounding. This shows the first week is considered to be very important from the mortality point of view and such vital areas along with its anthropometric dimensions were isolated by Sushruta under the category of Sadya Pranahar Marma where skilled management and rapid intervention are desired. Majority of these regions belong to fatal group as in case of head, abdomen and chest where all these Marma belong to fatal group. This indicates that head, neck and trunk are comparatively more significant than the extremities, which has been also observed by Acharya Sushruta. The reason has also been given in this context, the importance of blood has also been upheld through this observation and surgical behavior of the vessels of the extremities when they are amputated or disrupted following the contraction of the vessels and auto hemostat $[3,5,9]$.

The prognosis of Marma is variable depending upon the intensity, anthropometric area of wound, type of 


\section{Journal of Natural \& Ayurvedic Medicine}

weapon used, the depth of wound and the loss of type of tissue. It has also been observed by our Acharyas that the time limit of fatality of Sadhya pranahara Marma is seven days, Kalantara pranahara Marma is from 15th that to a month which is also same concept of modern surgery. Although there is no direct reference of Marma Sharir in modern surgery, even today every surgical attempt is made to avoid injury to the essential and dangerous structures or areas of the body; otherwise many problems occur in the present era. it is important to never have only the structural knowledge or morphological information on the Marma factors but the understanding of its anthropometric dimensions and minute information on gross and microscopic anatomy are also necessary to became a good clinician $[10,12]$.

\section{Conclusion}

Marma is very vital structure present in the body which causes pain, injury or even death when getting injured. It is defined as a location where there is the meeting point of Mamsa, Sira, Snayu, Asthi, and Sandhi and where the Prana resides. In Ayurvedic classics Marma is illustrated as the vital point in human body, the injury of which leads to severe pain or may be termination of life. Presents life is very fast and furious causes so many injuries during accidents, sports, and may be during daily activities which lead in to sever pain, injuries, deformity or even death. To overcome these circumstances we must know the vital parts of our body along with its anthropometric dimensions so that we take proper care to secure them from injuries. Anthropometric knowledge of Marma points play very important role in making of sports guards, pads, helmets, and other accessories to use in sports to avoid injuries. It is also helpful while during any surgical procedure by avoiding injury to the adjacent vital point. Every individual must know about the anthropometric dimensions of these vital points of our body so that ones can prevent them from injuries.

\section{References}

1. Samhita S, Acharya YT (2008) Susruta Samhita with Nibandha Sangraha of Dalhanacharya. 8 $^{\text {th }}$ (Edn.), Varanasi: Chaukhambha Orientalia, pp: 369.

2. Chaurasia BD (2004) Human Anatomy, part I.4 th (Edn.), New Delhi: BSP ublishers \& Distributors.

3. Samhita S, Atridev V, Banarasidas M (2002) New Delhi, pp: 324.
4. Ashtanga Hrudaya, Bhisagacarya HP (2005) Ashtanga Hrudayam with Sarvangasundara of Arunadatta \& Ayurvedarasayana of Hemadri. Varanasi: Chaukhambha Orientalia.

5. Acharya VJT (2008) Caraka Samhita revised by Caraka and Drdhabala with Sri Cakrapanidatta Ayurvedadipika Commentary in Sanskrit by, editor. $5^{\text {th }}$ (Edn.), Varanasi: Chaukhambha Sanskrit Sansthan.

6. Samhita S, Sharma A (2004) Sushrutvimarshanitika, volume II, chaukhamba surbharati prakashan pp: 99.

7. Pastore HA, Miaer MP (2001) Anatomical Consideration of Trimarma, (Sharir Rachna). World Journal of Pharmaceutical Research 4(9): 700-704.

8. Das S (2001) A Concise Textbook of Surgery, $3^{\text {rd }}$ (Edn.), Calcutta.

9. Chaurasia BD (2004) Human Anatomy, part I.4 th (Edn.), CBS Publishers \& Distributors. New Delhi.

10. Tanwar AK (2015) Importance of Ayurvedic Marma Vigyan", published in ayurveda- for healthy living monthly magazine, Govt of NCT Delhi.

11. Vijaynath A (2010) Comprehensive Study of Marma s in the Hasta (Hand) WSR to the Surface and Regional Anatomy, VSDM College of Ayurveda, Udupi.

12. Moore K, Dalley AF (2006) Clinically Oriented Anatomy, $5^{\text {th }}$ (Edn.), Baltimore: Lippincott Williams \& Wilkins, pp: 1209.

13. Samhita S, Tika V, Sharma A (2004) Volume II, Chaukhamba Surbharati Prakashan, pp: 99.

14. Samhita S, Acharya YT (2008) Susruta Samhita with Nibandha Sangraha of Dalhanacharya. 8 ${ }^{\text {th }}$ (Edn.), Varanasi: Chaukhambha Orientalia.

15. Samhita S, Tika V, Sharma A (2004) Volume II, Chaukhamba Surbharati Prakashan, pp: 17.

16. Hrudaya A, Bhisagacarya HP (2005) Ashtanga Hrudayam with Sarvangasundara of Arunadatta \& Ayurvedarasayana of Hemadri. Varanasi: Chaukhambha Orientalia.

17. Lahange (2016) A Review Study of Marma Sharir with Special Reference to Its Clinical Importance. World Journal of Pharmaceutical Research 5(10): 454-463. 


\section{Journal of Natural \& Ayurvedic Medicine}

18. Lahange (2017) A Critical Review Study on History of Indian Anatomy. World Journal of Pharmaceutical and Medical Research 3(6): 95-99.

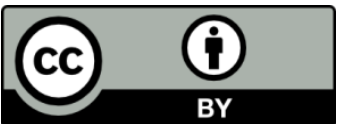

